\title{
PERANAN ORANG TUA DALAM PENDIDIKAN AGAMA ANAK USIA DINI
}

\author{
Yuliharti \\ Fakultas Tarbiyah \& Ilmu Keguruan UIN Suska Riau \\ yuliabbas@yahoo.com
}

\begin{abstract}
Abstrak: Undeniable, the parents have very important role to the future of a child, because the parents are the fist people who are recognized by child in his/her life. Parents are also the people who give first experience to a child, whether is bitter or sweet experience. Each of experience which is passed by the child, whether it is seen, heard or it is felt at her/his early life will become a very important element in construction of his/her personality. In this case, it is better for the parents to give the experience which is flange to the process of cultivation and education of religion at the same time in order to develop the potency of religion that has by the child.
\end{abstract}

.Kata Kunci: peranan, orang tua, pendidikan agama,usia dini

\section{PENDAHULUAN}

Anak merupakan anugerah sekaligus amanat dari Allah kepada orang tua. Tiap anak adalah anugerah karena tidak setiap orang dapat memilikinya. Setiap anak adalah amanat karena ia dilahirkan ke dunia dan Tuhan memilih orang tuanya sebagai orang yang tepat untuk merawat, mengasuh, dan membesarkannya sebagai calon pelanjut generasi. Dengan demikian, anak mempunyai kedudukan yang vital di tengah keluarga, masyarakat, dan bangsa, karena ia tidak saja sebagai perhiasan hidup bagi keluarga, tetapi lebih jauh 
dari itu ia merupakan estafet khalifah fil ardh.

Setiap orang tua pasti mendambakan anaknya menjadi manusia atau generasi penerus yang shalih, berkepribadian baik, patuh pada orang tua, santun kepada sesama, dan diredhoi oleh Allah SWT. Atau dengan kata lain, membawa kebahagiaan di dunia dan akhirat.

Untuk menggapai harapan itu, maka pendidikan agama pada usia dini merupakan satu upaya yang sangat penting untuk dilakukan oleh setiap orang tua di tengah keluarga dimana anak itu tumbuh dan berkembang, sehingga mereka mampu menjadi anak dambaan orang tua.

Pendidikan agama usia dini sesungguhnya memegang peranan dalam pembinaan kepribadian anak, pengembangan potensi-potensi yang dibawanya sejak lahir, serta merupakan upaya mempersiapkan generasi yang sempurna, di dunia dan akhirat. Di samping itu, dengan pendidikan agama anak akan mampu menghadapi dampak-dampak yang ditimbulkan oleh kemajuan ilmu pengetahuan dan teknologi. Apalagi melihat kenyataan yang akhir-akhir ini banyak diberitakan oleh media cetak maupun elektronik. Umpamanya orang tua banyak mengeluh karena perangai anaknya yang tidak mau patuh kepada mereka, terlibat dalam tindakan kenakalan, kekerasan, bahkan tindakan kriminal, seperti pembunuhan. Hal-hal tersebut membuat para orang tua harus intropeksi diri sekaligus perbaikan diri dalam pola didik terhadap anak-anak mereka.

Berdasarkan pemikiran tersebut di atas, penting untuk dikupas secara ringkas seputar peranan orang tua dalam pendidikan agama usia dini dengan tujuan agar setiap orang tua mampu menyadari pentingnya pendidikan agama usia dini serta mampu memberikan pendidikan agama secara baik dan tepat. Asumsi dalam hal ini adalah bahwa masih banyak orang tua yang mengabaikan pendidikan agama usia dini tersebut karena di antara mereka ada yang belum mengetahui pola pendidikan agama yang bagaimana yang harus mereka laksanakan terhadap anak-anak mereka.

\section{PEMBAHASAN}

\section{Pengertian Pendidikan Agama Anak Usia Dini}

Pendidikan Anak Usia Dini (PAUD) adalah suatu upaya pembinaan yang ditujukan kepada anak sejak lahir sampai dengan usia enam tahun yang dilakukan melalui pemberian rangsangan pendidikan untuk membantu pertumbuhan dan perkembangan jasmani dan rohani agar anak memiliki kesiapan dalam memasuki pendidikan lebih lanjut.

Secara umum, tujuan pendidikan anak usia dini adalah mengembangkan berbagai potensi keagamaan anak sejak dini sebagai persiapan untuk hidup di dunia ini dan dapat menyesuaikan diri dengan lingkungannya dengan baik 
sesuai dengan nilai-nilai agama Islam.

\section{Peranan Orang Tua dalam Pendidikan Anak Usia Dini}

Dalam konteks Islam, tanggung jawab orang tua (ayah dan ibu) terhadap pendidikan agama anak merupakan suatu keharusan, yang secara fiqih dapat disebut sebagai "fardhu 'ain". Hal ini tergambar dalam Al-Quran maupun dalam hadis Nabi saw. Dalam Al-Quran digambarkan bahwa setiap anak itu sudah diberikan oleh Allah SWT potensi untuk berbuat baik dan buruk. Seperti dalam surat Asy-Syamsi ayat 8 yang berbunyi:

\$yù 1

Artinya: Maka Allah mengilhamkan kepada jiwa itu (jalan) kefasikan dan ketakwaannya.

Demikian juga dalam hadis Nabi saw:

اوينصر انه يججسانه او يهودنه فابو اه الفطرة على يولد مولود كل : كل Artinya: "Setiap anak dilahirkan dalam keadaan suci, maka bapaknyalah yang menjadikannya Yahudi, Majusi, ataupun Nasrani"

Ayat Al-Quran dan Hadis tersebut di atas menerangkan betapa pentingnya peranan orang tua dalam mengembangkan potensi-potensi yang sudah dibawa oleh anak sejak lahir. Orang tualah yang akan mewarnai dan menentukan kepribadian anak di masa depan. Potensi-potensi yang dibawa anak itu hanya akan dapat berkembang dengan baik melalui pendidikan yang diberikan oleh orang tua sejak usia dini (sejak lahir), yaitu dalam bentuk pendidikan agama.

Tanggung jawab orang tua terhadap pendidikan agama anak juga dilukiskan oleh Al-Quran dalam bentuk kisah. Hal ini dapat dilihat, umpamanya, bagaimana tanggung jawab seorang ayah terhadap anaknya yang ditunjukan oleh kisah Lukman, seorang bapak yang bijak. Al-Quran menggambarkan bagaimana Lukman menanamkan arti penting ketauhidan kepada anaknya, dan syirik itu adalah kezaliman yang besar. Begitu juga, mengapa pula anak harus menghormati orang tua, perlunya membiasakan diri berbuat baik kepada orang lain, mendirikan sholat, berbuat amar ma'ruf dan nahi mungkar, berlaku sabar, tidak berlaku sombong, sederhana dan bertutur kata yang bagus. Perlunya orang tua mempunyai tanggung jawab agar anak tetap melaksanakan ajaran agama diutarakan oleh Al-Quran dalam bentuk dialog antara Ya'kub dan anak-anaknya apakah mereka akan memegang teguh ketauhidan, yang dijawab oleh anak-anaknya dengan kepastian bahwa mereka akan tetap memeluk agama Ibrahim, Ismail, dan Ishak.

Pembentukan sebuah komunitas agamis, dalam bentuk keluarga, yang terdiri dari ayah, ibu, anak, dan cucu, memang perlu disiapkan dan direncanakan dari awal. Calon orang tua perlu berdoa sebelum adanya tanda- 
tanda kelahiran agar diberi anak dan cucu yang baik. Dalam hal ini, Allah memberikan contoh keluarga Imran sebagai keluarga pilihan yang melebihi orang lain pada masanya. Al-Quran menggambarkan bagaimana isteri Imran, sewaktu hamil, bernazar kepada Tuhan kiranya anak yang dikandungnya menjadi hamba yang sholeh dan berkhidmat. Masalah yang sama juga digambarkan Al-Quran bagaimana Zakaria berdoa semoga diberi anak yang baik, anak yang sholeh. Zakaria menyadari bahwa selama ini isterinya adalah perempuan yang tidak dapat mempunyai anak (mandul). Akan tetapi, karena kemauan Zakaria yang kuat untuk memeperoleh anak dan berdoa dengan tulus, akhirnya Allah SWT memberinya seorang anak.

Demikian Al-Quran menggambarkan betapa pentingnya pendidikan agama dalam pembentukan pribadi anak.

Dalam haditsnya, Nabi Muhammad saw telah menggambarkan beberapa bentuk prilaku yang harus dilakukan oleh orang tua dalam menanamkan ajaran agama sebagai perwujudan dari pengembangan potensi keagamaan anak sehingga tumbuh menjadi anak yang bertakwa. Misalnya, sabda Nabi saw yang artinya:

"Kewajiban ayah terhadap anaknya adalah memberinya nama yang baik, mendidiknya dengan adab yang baik, menyediakan tempat tinggal yang baik, mengajarinya tulis baca dan berenang serta memanah, memberinya konsumsi yang baik (halal dan bergizi), dan mengawinkannya bila mendapat jodoh."(HR.Al-Hakim dan Abu Al-Syaikh)

"Ajaklah anakmu melakukan sholat bila berumur tujuh tahun, dan dipukul (diberi sangsi) jika meninggalkan sholat bila telah berumur 10 tahun dan pisahkan tempat tidur mereka"(HR.Ahmad,Abu Daud,Al-Hakim)

`Amr bin Abi Salamah Radhiyallah `anhu berkata, "Ketika aku masih kecil di bawah asuhan Rasulullah saw, aku biasa menjulurkan tanganku ke dalam piring ke segala arah, maka Rasulullah saw bersabda kepadaku: "Wahai anak, ucapkanlah bismillah, makanlah dengan tangan kananmu dan makanlah apa yang dekat denganmu"

Ibnu Abbas berkata: "Pernah ketika aku kecil aku berada di belakang Nabi saw, lalu beliau berkata kepadaku: "Wahai anak, sesungguhnya aku akan mengajarkan kepadamu beberapa kata. Jagalah Allah niscaya Allah akan menjagamu, jagalah Allah niscaya engkau dapatkan Dia di hadapanmu. Jika engkau meminta maka memintalah kepada Allah dan jika engkau meminta tolong, minta tolonglah kepada Allah..

Muhammad Ar-Rabah Abu Abdirrahman menjelaskan dalam bukunya yang berjudul Ahkamul Maulud fi Sunnatil Muthahharah, beberapa hal yang harus dilakukan atas kelahiran anak, yaitu adzan pada telinga anak yang baru lahir, aqiqah, mencukur rambut terhadap anak sesuai dengan petunjuk Nabi 
saw, yaitu: menyampaikan berita gembira bayi, memberi nama, dan mengkhitankannya.

Di samping apa yang telah diajarkan Nabi saw, interaksi antara orang tua dan anak harus diisi dengan penanaman moral Islam, pengamalan ajaran agama, pemberian contoh tauladan. Dalam berinteraksi, orang tua melakukan perannya yang secara langsung mempengaruhi perkembangan kehidupan anak. Pakar parenting Marc H.Bornstein (1998) menyebutkan empat inti peran orang tua, yakni; 1) Nurturant Caregiving, yaitu pemenuhan kebutuhan biologis, fisik, dan kesehatan anak; 2) Material Caregiving, yaitu pemenuhan kebutuhan yang bersifat material, seperti rumah, alat bermain, buku, dll; 3) Social Caregiving, yaitu pemenuhan kebutuhan emosional dan interpersonal anak seperti memberikan perhatian dalam berbagai bentuk, mendengar, memuji, membantu anak untuk dapat mengontrol emosi dan afeksinya, memberikan disiplin dan kontrol yang baik; 4) Didactic Caregiving, yaitu, penggunaan strategi untuk menstimulasi anak agar mengerti dan terlibat dalam lingkungannya.

Keempat hal tersebut perlu dilakukan oleh orang tua terhadap anak sejak lahir dan tidaklah cukup kalau yang diperhatikan hanya sebagian saja. Zakiyah Darajat menjelaskan tentang peran orang tua dalam pendidikan agama seorang anak, yaitu sebagai pembina utama bagi kebahagiaan anak, pembina kepribadian anak, dan perawat kejiwaan anak. Orang tua, terutama ibu, adalah orang yang pertama yang dikenal oleh anak, orang pertama yang memberikan pengalaman langsung kepada anak, baik menyenangkan maupun tidak. Hal ini bukan berarti bahwa seorang ayah tidak berperan dalam mendidik anak. Secara tradisional, peran ayah sering bersifat tidak langsung, dalam arti bahwa seorang ayah bertanggung jawab memberikan ketenangan, kedamaian kepada istrinya sehingga ia senantiasa dalam keadaan tenang dalam mendidik anaknya. Oleh karena itu, pemenuhan segala kebutuhan keluarga atau mencari nafkah menjadi tugas prioritas seorang ayah dalam keluarga. Ibu adalah orang yang selalu berada di samping anaknya, oleh karena itu pengalaman, perasaannya banyak mempengaruhi anaknya. Untuk itu seorang ibu sangat dituntut kemampuannya agar mampu memberikan pengalaman yang baik dalam mendidik dan membina keluarga.

Hal ini sesuai dengan hadis Nabi saw yang menyatakan bahwa "surga itu di bawah telapak kaki ibu." Hadis ini sangat sarat dengan pesan psikologisnya dimana ibu adalah sumber ketenangan, kedamaian dan kebahagiaan keluarga. Ketenangan dan kedamaian rumah tangga sangat ditentukan oleh kemampuan ibu dalam menjalankan tugasnya dirumah tangga. Oleh karena itu, sudah merupakan tugas dan tanggung jawab suami untuk dapat menciptakan situasi dan kondisi si ibu agar mampu menjalankan tugasnya sebagai sumber 
ketenangan keluarga. Di sini jelaslah bahwa tanggung jawab pendidikan anak merupakan tanggungjawab ayah dan ibu, karena keduanya sama-sama memiliki keterkaitan dalam menjalankan tugasnya. Jadi keduanya tidak berjalan sendiri-sendiri dan membutuhkan kerja sama yang baik di antara keduanya.

Pengalaman yang dimiliki oleh orang tua sangat mempengaruhi penanaman pendidikan agama dan pembinaan kepribadian pada anak usia dini. Jika pengalaman yang diberikan oleh orang tua baik, maka baiklah yang akan memenuhi pribadi anak. Sebaliknya jika buruk, maka buruk pulalah pribadi anak. Pengalaman anak merupakan unsur penting dalam pembinaan kepribadiannya. Orang tua harus mampu menghindari hal-hal yang bisa membuat anak menderita, seperti hubungan yang tidak harmonis diantara orang tua, tidak adanya perhatian, dan disiplin yang tidak menekan. Keteladan orang tua sangat berarti dalam pembinaan iman, aqidah, akhlak dan sosial anak. Orang tua tidak boleh bersikap keras dan mengusir anak apalagi menyumpahinya, karena hal itu akan berpengaruh kepada kejiwaan anak.

Oleh karena itulah orang tua harus mampu membahagiakan anaknya, yaitu dengan cara mereka harus merasa bahagia dan mampu memahami anaknya dari segala aspek pertumbuhan, jasmani, rohani, sosial dalam semua tingkat umur. Orang tua harus mampu mendidik anaknya dengan cara yang akan membawa kepada kebahagiaan dan pertumbuhan anak yang sehat.

Pada saat ini, peran orang tua terhadap anak belum optimal. Banyak orang tua dengan berbagai macam sebab tidak dapat melaksanakan peranya atau hanya dapat menjalankan sebagian perannya. Akibatnya adalah hak-hak mereka terampas. Kehidupan anak memperlihatkan gejala dan tingkah laku yang menyimpang. Adanya gejala peningkatan tingkah laku menyimpang pada anak mengindikasikan terjadinya krisis peranan orang tua dalam melaksanakan tanggung jawabnya.

Terjadinya krisis peranan orang tua pada saat ini dapat dikembalikan kepada beberapa faktor, antara lain; 1) Gempuran informasi dan tayangan yang disajikan media massa sebagai akibat dari revolusi informasi dan komunikasi; 2) Kesibukan orang tua; 3 ) Berbagai keterbatasan yang dimiliki oleh orang tua seperti, ekonomi, pendidikan, dan intelektual; 4) Faktor internal orang tua yang sudah terinfeksi oleh budaya global yang negatif, seperti budaya hedonisme yang melahirkan sikap permisif.

Oleh karena itu, dalam masyarakat yang sedang berkembang dan terbuka seperti pada saat ini, diperlukan gerakan penyadaran kembali tentang pentingnya tanggung jawab orang tua terhadap pendidikan agama anak. Diperlukan penyadaran, karena diasumsikan banyak orang tua yang tidak menyadari bagaimana pengaruh media massa dalam memperkenalkan nilai- 
nilai budaya yang tidak sejalan dengan nilai-nilai agama. Hadis Nabi yang menjelaskan tentang fitrah anak dan tentang peranan orang tua, seperti yang telah dikemukakan, adalah pengungkapan bahwa pengaruh orang tua sangat dominan dalam menentukan kepribadian anak, apakah akan menjadi Yahudi, Nasrani atau Majusi. Pada saat ini diasumsikan bahwa pengaruh di luar orang tua, seperti media massa, jauh lebih besar dibandingkan dengan pengaruh orang tua. Oleh karena itu, pendidikan anak menjadi perebutan pengaruh antara orang tua dan media massa.

Selain itu, usaha revitalisasi peranan orang tua terhadap pendidikan anak perlu dilakukan dengan program pemberdayaan orang tua dalam bidang ekonomi, intelektual, dan pendidikan. Terlihat gejala di dalam masyarakat, terutama perkotaan, orang tua dengan keterbatasan ekonomi, apalagi diikuti oleh keterbatasan pendidikan, mengalami kesukaran dalam melaksanakan fungsi bimbingan dan pengawasan terhadap anaknya. Usaha pemberdayaan ini merupakan tanggung jawab negara dan masyarakat. Lembaga swadaya masyarakat dapat dan perlu mengambil peranan dalam hal ini. Kegiatan ini dapat dilakukan dengan bantuan biaya pemerintah maupun sumber dana lainnya.

\section{Kejahatan Orang Tua terhadap Anak}

Rasulullah saw. sangat penyayang terhadap anak-anak, baik terhadap keturunan beliau sendiri ataupun anak orang lain. Abu Hurairah r.a. meriwayatkan bahwa suatu ketika Rasulullah saw. mencium Hasan bin Ali dan didekatnya ada Al-Aqraâ bin Hayis At-Tamimi sedang duduk. Ia kemudian berkata, "Aku memiliki sepuluh orang anak dan tidak pernah aku mencium seorang pun dari mereka." Rasulullah saw. segera memandang kepadanya dan berkata, "Man laa yarham laa yurham," barangsiapa yang tidak mengasihi, maka ia tidak akan dikasihi". ${ }^{4}$ (HR. Bukhari di Kitab Adab, hadits nomor 5538).

Bahkan dalam shalat pun Rasulullah saw. tidak melarang anak-anak dekat dengan beliau. Hal ini didapat dari cerita Abi Qatadah, bahwa "Suatu ketika Rasulullah saw. mendatangi kami bersama Umamah binti Abil Ash , anak Zainab, putri Rasulullah saw. Beliau meletakkannya di atas bahunya. Beliau kemudian shalat dan ketika rukuk, Beliau meletakkannya dan saat bangkit dari sujud, Beliau mengangkat kembali. ${ }^{5}$ (HR. Muslim dalam Kitab Masajid wa Mawadhiâush Shalah, hadits nomor 840).

Peristiwa itu bukan kejadian satu-satunya yang terekam dalam sejarah. Abdullah bin Syaddad juga meriwayatkan dari ayahnya bahwa, "Ketika waktu datang shalat Isya, Rasulullah saw. datang sambil membawa Hasan dan Husain. Beliau kemudian maju (sebagai imam) dan meletakkan cucunya. Beliau kemudian takbir untuk shalat. Ketika sujud, Beliau pun memanjangkan 
sujudnya. Ayahku berkata, Saya kemudian mengangkat kepalaku dan melihat anak kecil itu berada di atas punggung Rasulullah saw. yang sedang bersujud. Saya kemudian sujud kembali. Setelah selesai shalat, orang-orang pun berkata, "Wahai Rasulullah, saat sedang sujud di antara dua sujudmu tadi, engkau melakukannya sangat lama, sehingga kami mengira telah terjadi sebuha peristiwa besar, atau telah turun wahyu kepadamu." Beliau kemudian berkata, "Semua yang engkau katakan itu tidak terjadi, tapi cucuku sedang bersenangsenang denganku, dan aku tidak suka menghentikannya sampai dia menyelesaikan keinginannya." ${ }^{6}$ (HR. An-Nasai dalam Kitab At-Thathbiq, hadits nomor 1129).

Usamah bin Zaid ketika masih kecil punya kenangan manis dalam pangkuan Rasulullah saw. "Rasulullah saw. pernah mengambil dan mendudukkanku di atas pahanya, dan meletakkan Hasan di atas pahanya yang lain, kemudian memeluk kami berdua, dan berkata, Ya Allah, kasihanilah keduanya, karena sesungguhnya aku mengasihi keduanya." ${ }^{7}$ (HR. Bukhari dalam Kitab Adab, hadits nomor 5544).

Begitulah Rasulullah saw. bersikap kepada anak-anak. Secara halus Beliau mengajarkan kepada umatnya untuk memperhatikan anak-anaknya. Beliau juga mencontohkan dalam praktik bagaimana bersikap kepada anak dengan penuh cinta, kasih, dan kelemahlembutan. Karena itu, setiap sikap yang bertolak belakang dengan apa-apa yang dicontohkan oleh Rasulullah saw., adalah bentuk kejahatan kepada anak-anak. Setidaknya, ada empat jenis kejahatan yang kerap dilakukan orang tua terhadap anaknya sebagai berikut.

Pertama, memaki dan menghina anak.

Bagaimana orang tua dikatakan menghina anak-anaknya? Yaitu ketika seorang ayah menilai kekurangan anaknya dan memaparkan setiap kebodohannya. Lebih jahat lagi jika itu dilakukan di hadapan teman-teman si anak. Termasuk dalam kategori ini adalah memberi nama kepada si anak dengan nama yang buruk. Seorang lelaki penah mendatangi Umar bin Khattab seraya mengadukan kedurhakaan anaknya. Umar kemudian memanggil putra orang tua itu dan menghardiknya atas kedurhakaannya. Tidak lama kemudan anak itu berkata, "Wahai Amirul Mukminin, bukankah sang anak memiliki hak atas orang tuanya?" "Betul," jawab Umar. "Apakah hak sang anak?" "Memilih calon ibu yang baik untuknya, memberinya nama yang baik, dan mengajarkannya Al-Qurân," jawab Umar. "Wahai Amirul Mukminin, sesungguhnya ayahku tidak melakukan satu pun dari apa yang engkau sebutkan. Adapun ibuku, ia adalah wanita berkulit hitam bekas hamba sahaya orang majusi; ia menamakanku Juâlan (kumbang), dan tidak mengajariku satu huruf pun dari Al-Quran," kata anak itu. Umar segera memandang orang tua itu dan berkata kepadanya, "Engkau datang untuk mengadukan kedurhakaan 
anakmu, padahal engkau telah durhaka kepadanya sebelum ia mendurhakaimu. Engkau telah berbuat buruk kepadanya sebelum ia berbuat buruk kepadamu."

Rasulullah saw. sangat menekankan agar umatnya memberi nama yang baik kepada anak-anak. Abu Darda meriwayatkan bahwa Rasulullah saw. bersabda, "Sesungguhnya kalian akan dipanggil pada hari kiamat dengan nama-nama kalian dan nama ayah kalian, maka perbaikilah nama kalian." ${ }^{8}$ HR. Abu Dawud dalam Kitab Adab, hadits nomor 4297).

Karena itu Rasulullah saw. kerap mengganti nama seseorang yang bermakna jelek dengan nama baru yang baik. Atau, mengganti julukan-julukan yang buruk kepada seseorang dengan julukan yang baik dan bermakna positif. Misalnya, Harb (perang) menjadi Husain, Huznan (yang sedih) menjadi Sahlun (mudah), Bani Maghwiyah (yang tergelincir) menjadi Bani Rusyd (yang diberi petunjuk). Rasulullah saw. memanggil Aisyah dengan nama kecil Aisy untuk memberi kesan lembut dan sayang. Jadi, adalah sebuah bentuk kejahatan bila kita memberi dan memanggil anak kita dengan sebutan yang buruk lagi dan bermakna menghinakan dirinya.

Kedua, melebihkan seorang anak dari yang lain.

Memberi sesuatu yang lebih kepada anak kesayangan dan mengabaikan anak yang lain adalah bentuk kejahatan orang tua kepada anaknya. Sikap ini adalah salah satu faktor pemicu putusnya hubungan silaturrahmi anak kepada orang tuanya dan pangkal dari permusuhan antar saudara.

Nuâman bin Basyir bercerita, "Ayahku menginfakkan sebagian hartanya untukku. Ibuku Amrah binti Rawahah kemudian berkata, "Saya tidak suka engkau melakukan hal itu," sehingga ia menemui Rasulullah. Ayahku kemudian berangkat menemui Rasulullah saw. sebagai saksi atas sedekah yang diberikan kepadaku. Rasulullah saw. berkata kepadanya, "Apakah engkau melakukan hal ini kepada seluruh anak-anakmu?" Ia berkata, “Tidak". Rasulullah saw. berkata, `Bertakwalah kepada Allah dan berlaku adillah kepada anak-anakmu." Ayahku kemudian kembali dan menarik lagi sedekah itu. ${ }^{10}$ (HR. Muslim dalam Kitab Al-Hibaat, hadits nomor 3055).

Puncak kezaliman kepada anak adalah ketika orang tua tidak bisa memunculkan rasa cinta dan sayangnya kepada anak perempuan yang kurang cantik, kurang pandai, atau cacat salah satu anggota tubuhnya. Padahal, tidak cantik dan cacat bukanlah kemauan si anak. Apalagi tidak pintar pun itu bukanlah dosa dan kejahatan. Justru, setiap keterbatasan anak adalah pemacu bagi orang tua untuk lebih mencintainya dan membantunya. Rasulullah saw. bersabda, "Rahimallahu waalidan aana waladala birrihi," (semoga Allah mengasihi orang tua yang membantu anaknya di atas kebaikan). (HR. Ibnu Hibban)

Ketiga, mendoakan keburukan bagi si anak. 
Abu Hurairah r.a. berkata bahwa Rasulullah saw. bersabda, "Tsalatsatu daawaatin mustajaabaatun: daâwatu al-muzhluumi, watu al-musaafiri, dawatu waalidin ala walidih," (Ada tiga doa yang dikabulkan: doa orang yang teraniaya, doa musafir dan doa (keburukan) orang tua atas anaknya.) ${ }^{11}$ (HR. Tirmidzi dalam Kitab Birr wash Shilah, hadits nomor 1828). Entah apa alasan yang membuat seseorang begitu membenci anaknya. Saking bencinya, seorang ibu bisa sepanjang hari lidahnya tidak kering mendoakan agar anaknya celaka, melaknat dan memaki anaknya. Sungguh, ibu itu adalah wanita yang paling bodoh. Setiap doanya yang buruk, setiap ucapan laknat yang meluncur dari lidahnya, dan setiap makian yang diucapkannya bisa terkabul lalu menjadi bentuk hukuman bagi dirinya atas semua amal lisannya yang tak terkendali.

Seseorang pernah mengadukan putranya kepada Abdullah bin Mubarak. Abdullah bertanya kepada orang itu, "Apakah engkau pernah berdoa (yang buruk) atasnya?" Orang itu menjawab: "Ya." Abdullah bin Mubarak berkata, "Engkau telah merusaknya." Doa buruk bagi anak adalah bentuk kejahatan, anak akan bertambah rusak moralnya jika si anak yang sebelumnya sudah durhaka kepada orang tuanya.

Keempat, tidak memberi pendidikan kepada anak

Ada syair Arab yang berbunyi, "Anak yatim itu bukanlah anak yang telah ditinggal orang tuanya dan meninggalkan anak-anaknya dalam keadaan hina. Sesungguhnya anak yatim itu adalah yang tidak dapat dekat dengan ibunya yang selalu menghindar darinya, atau ayah yang selalu sibuk dan tidak ada waktu bagi anaknya.

Kata kunci untuk hal ini adalah "Perhatian". Bentuk perhatian yang tertinggi orang tua kepada anaknya adalah memberikan pendidikan yang baik. Tidak memberikan pendidikan yang baik dan maksimal adalah bentuk kejahatan orang tua terhadap anak. Dan segala kejahatan pasti berbuah ancaman yang buruk bagi pelakunya.

Perintah untuk mendidik anak adalah bentuk realisasi iman. Perintah ini diberikan secara umum kepada kepala rumah tangga tanpa memperhatikan latar belakang pendidikan dan kelas sosial. Setiap ayah wajib memberikan pendidikan kepada anaknya tentang agamanya dan memberi keterampilan untuk bisa mandiri dalam menjalani hidupnya kelak. Jadi, berilah pendidikan yang bisa mengantarkan si anak hidup bahagia di dunia dan bahagia di akhirat.

Perintah ini diberikan Allah swt. dalam bentuk umum. "Hai orang yang beriman, peliharalah dirimu dan keluargamu dari api neraka yang bahan bakarnya dari manusia dan batu; penjaganya malaikat-malaikat yang kasar, yang keras, yang tidak mendurhakai Allah terhadap apa yang diperintahkanNya kepada mereka dan selalu mengerjakan apa yang 
diperintahkan." ${ }^{12}$ (QS. At-Tahrim: 6)

Adalah sebuah bentuk kejahatan terhadap anak jika ayah-ibu tenggelam dalam kesibukan, sehingga lupa mengajarkan anaknya cara shalat. Meskipun kesibukan itu adalah mencari rezeki yang digunakan untuk menafkahi anakanaknya. Jika ayah-ibu berlaku seperti ini, keduanya telah melanggar perintah Allah di surat Thaha ayat 132. "Dan perintahkanlah kepada keluargamu mendirikan shalat dan bersabarlah kamu dalam mengerjakannya. Kami tidak meminta rezeki kepadamu, Kamilah yang memberi rezeki kepadamu. Dan akibat (yang baik) itu adalah bagi orang yang bertakwa."

Rasulullah saw. bersabda, "Ajarilah anak-anakmu shalat saat mereka berusia tujuh tahun, dan pukullah mereka (bila tidak melaksanakan shalat) pada usia sepuluh tahun." (HR. Tirmidzi dalam Kitab Shalah, hadits nomor 372).

Para ulama sepakat, tidak ada pemberian yang baik dari orang tua kepada anaknya, selain memberi pendidikan yang baik. Begitu hadits dari Ayyub bin Musa yang berasal dari ayahnya dan ayahnya mendapat dari kakeknya bahwa Rasulullah saw. bersabda, "Maa nahala waalidun waladan min nahlin afdhala min adabin hasanin," (tak ada yang lebih utama yang diberikan orang tua kepada anaknya melebihi adab yang baik). (HR. Tirmidzi dalam Kitab Birr wash Shilah, hadits nomor 1875. Tirmidzi berkata, Ini hadits mursal.)

\section{SIMPULAN}

Berdasarkan paparan singkat di atas, maka penulis dapat mengambil suatu kesimpulan bahwa orang tua sangat berperanan dalam menentukan masa depan anak. Baik atau tidaknya kepribadian anak ditentukan dan diwarnai oleh pendidikan yang diberikan orang tua kepada anak. Untuk itu, supaya anak menjadi manusia yang berkepribadian yang baik, akhlak yang santun, orang tua harus mampu memberikan didikan yang baik kepada anak. Untuk melakukan semua ini, tentunya orang tua harus selalu meningkatkan kualitas dirinya, baik kualitas ilmu, ekonomi, dan sosialnya, demi suksesnya dalam melaksanakan tanggung jawabnya terhadap anak-anak mereka. 